\title{
Acculturation to Western Society as a Risk Factor for High Blood Pressure: A Meta-Analytic Review
}

Timothy B. Smith

Brigham Young University, tbs@byu.edu

Patrick R. Steffen

Brigham Young University, steffen@byu.edu

Michael Larson

University of Florida

Leon Butler

Auburn University

Follow this and additional works at: https://scholarsarchive.byu.edu/facpub

Part of the Counseling Psychology Commons

\section{Original Publication Citation}

Steffen, P. R., Smith, T. B., Larson, M., \& Butler, L. (2006). Acculturation to Western Society as a Risk Factor for High Blood Pressure: A Meta-Analytic Review. Psychosomatic Medicine, 68(3), 386-397. doi:10.1097/01.psy.0000221255.48190.32

\section{BYU ScholarsArchive Citation}

Smith, Timothy B.; Steffen, Patrick R.; Larson, Michael; and Butler, Leon, "Acculturation to Western Society as a Risk Factor for High Blood Pressure: A Meta-Analytic Review" (2005). Faculty Publications. 1968. https://scholarsarchive.byu.edu/facpub/1968 accepted for inclusion in Faculty Publications by an authorized administrator of BYU ScholarsArchive. For more information, please contact ellen_amatangelo@byu.edu. 
Running head: ACCULTURATION AND BLOOD PRESSURE

Acculturation to Western Society as a Risk Factor for High Blood Pressure:

A Meta-Analytic Review

Patrick R. Steffen, Ph.D., Timothy B. Smith, Ph.D., Michael Larson¹, B.S., Leon Butler², B.S. Brigham Young University

Steffen, P. R., Smith, T. B., Larsen, M., \& Butler, L. (2006). Acculturation to Western society as a risk factor for high blood pressure: A meta-analytic review. Psychosomatic Medicine, 68, 386397.

Current Affiliations: ${ }^{1}$ University of Florida, Gainesville, FL; ${ }^{2}$ Auburn University, Auburn, AL

CORRESPONDING AUTHOR: Patrick R. Steffen, Ph.D., 284 Taylor Building, Brigham Young University, Provo, UT, 84602 (phone (801) 422-7747; fax (801) 422-0163; email steffen@byu.edu)

Word Count: 11,205 (5,732 not including references, Tables, and Figures) Number of Tables and Figures: 4 


\section{Running head: ACCULTURATION AND BLOOD PRESSURE}

Acculturation to Western Society as a Risk Factor for High Blood Pressure:

$$
\text { A Meta-Analytic Review }
$$

Patrick R. Steffen, Timothy B. Smith, Michael Larson, Leon Butler

Brigham Young University 


\begin{abstract}
Objective: A number of studies have documented that acculturation to Western society is related to an increase in blood pressure. Although there is evidence that higher socioeconomic status appears related to better cardiovascular health, increasing acculturation to Western society appears related to worse cardiovascular health. The purpose of this meta-analysis was to investigate the association between acculturation and blood pressure.
\end{abstract}

Method: Literature searches yielded 125 relevant research manuscripts, which were coded by teams of two independent raters. Measures of association (effect sizes) were extracted for both systolic blood pressure (SBP) and diastolic blood pressure (DBP) readings. Random effects models were used to analyze the resulting data.

Results: The overall effect sizes associated with acculturation were .28 for SBP and .30 for DBP, with increasing acculturation to Western society related to higher BP. More acculturated individuals had an average of $4 \mathrm{~mm} \mathrm{Hg}$ higher BP than less acculturated individuals, which is similar to the effect sizes of known risk factors for high blood pressure such as diet and physical activity. The effects of acculturation on BP appear to be universal, with similar effect sizes found across all regions of the world. Change in BP due to acculturation was not related to BMI or cholesterol but was related to length of residence in the new culture, with the largest effect sizes seen upon initial entry and then decreasing rapidly within the first few years. Sudden cultural changes, such as migration from rural to urban settings, resulted in the largest effect sizes, which finding supports the hypothesis that the stress of cultural change is important role in the acculturation effect.

Conclusions: Acculturation to Western society is associated with higher blood pressure, and the distress associated with cultural change appears to be more influential than changes in diet or 
physical activity. Future studies would benefit from investigating how cultural change affects health and examining whether some non-Western cultural values and practices are health protective.

Key Words: Acculturation, Blood Pressure, Stress, Health Behavior, Meta-Analysis 
Acculturation to Western Society as a Risk Factor for High Blood Pressure:

\section{A Meta-Analytic Review}

Researchers have long hypothesized that acculturation to Western society is associated with increases in blood pressure (BP) (1-5). Individuals from Western societies typically have higher BP than those from other regions of the world, with this difference decreasing as nonWesterners adapt to Western culture (6). Immigrants to the United States and Europe from Africa, Asia, Latin America, and Polynesia have consistently shown higher BP with increasing levels of acculturation to Western society (7-10). Industrialization, modernization, and urbanization within non-Western countries (all of which are related to Westernization) are also associated with higher BP levels (7, 11-13).

Although a large number of studies have documented the negative effects of acculturation to Western society on BP $(10,13-14)$, there is some debate as to why acculturation adversely affects BP (15). Two hypotheses repeatedly cited in the literature state that acculturation to Western society is associated with increase in BP because of 1) stressors associated with cultural change and 2) health behavior changes (diet, physical activity, etc.). Stressors associated with acculturation to Western society include decreased social support and increased job demands (12-13), which factors are consistently associated with higher BP (16). Non-Westerners typically have larger social networks and more social support than Westerners, and as nonWesterners adapt to a Western lifestyle, their level of social support decreases (17). NonWesterners are less likely to work in stressful job conditions than are Westerners, and adaptation to new styles of work is a potent stressor associated with the acculturation process (13). Another factor related to stress in Western societies is socioeconomic status (SES), with lower SES related to higher BP independent of health care access and health behavior (18-19). Non- 
Western immigrants to Western countries have lower SES and lower BP as compared to Westerners (20-21). As non-Westerners acculturate to Western society, however, the SES/BP relationship begins to follow the Western pattern with lower SES related to higher BP (20-21). Changes in health behaviors associated with acculturation to Western society include poorer diet and less physical activity $(5,15)$. However, few studies have directly examined changes in diet or physical activity among acculturating populations. Rather, studies have typically examined variables related to diet and physical activity, particularly BMI, cholesterol, and salt intake. Unhealthy changes in diet and physical activity lead to increases in BMI, cholesterol, and salt intake (22). A number of studies have found that increased acculturation is associated these factors (15). Not all studies, however, have found a relationship with acculturation. Salt intake, for example, is not always related to degree of acculturation $(13,23)$, and at least one study actually found higher levels of salt intake among the less acculturated, lower BP group (24).

Diet and physical activity are traditional risk factors in the development of high BP (22), but stress is not. In their public health announcements organizations such as the National Institutes of Health and the American Heart Association do not include stress as a risk factor for high BP. Recent longitudinal studies, however, have found that changes in stress predict changes in BP. For example, changes in work stress predict changes in BP over time, with increases in work stress predicting higher BP and decreases in work stress predicting lower BP (25). Similarly, changes in financial stress predict changes in BP over time, with increases in financial stress predicting higher BP and decreases in financial strain predicting lower BP (26). In addition, baseline marital distress predicts changes in BP over time, with higher levels of marital distress predicting higher BP (27). In short, distress in any form may increase BP. 
Although both distress and health behaviors contribute to increases in BP, some studies indicate that among acculturating populations the distress associated with cultural change may be more significant in predicting increased BP than changes in diet and health behaviors. First, less acculturated groups have lower BP than more acculturated groups, even when negative health behaviors are controlled $(8,13,23)$. For example, Japanese immigrants to the United States who continue living a traditional Japanese lifestyle have lower BP than those who acculturate to a Western lifestyle, even after controlling for traditional BP risk factors such as diet and body mass (8). Similarly, Italian nuns, who live a relatively stress free lifestyle, had significantly lower BP as compared to demographically matched Italian laywomen, even though they did not differ significantly in regards to body mass, cholesterol, or salt intake (23). Second, most of the negative impact of acculturation upon BP appears to happen within the first few years of cultural contact $(9,28-29)$. Samburu tribesmen in Kenya, who have low BP and do not show a rise in BP with age, showed significant increases in BP within three years of joining the Kenyan army, with this change being unrelated to body mass or cholesterol (9). Recently arrived Ethiopian immigrants to Israel have significantly lower BP as compared to Israelis, but after three to four years of residence in Israel, there are no significant differences in BP between the immigrants and the Israelis (28-29). Thus the literature lends some support to the postulate that increased levels of distress among acculturating populations are more strongly associated with increased $\mathrm{BP}$ than changes in diet or health behaviors. However, the research literature on the topic of BP and acculturation is quite large, making it difficult to draw any certain conclusions based upon a traditional narrative review.

Although over 100 research studies have investigated the effect of acculturation on BP, no attempts to synthesize this large corpus of research have been made previously. Although this 
area of inquiry has many implications for public health $(11-15,22)$, particularly with acculturation to Western society increasing rapidly across the globe, the only firm conclusion that has been reached in the literature is that a positive relationship exists between blood pressure increases and acculturation. The overall magnitude of that increase remains unknown, particularly across different contexts.

We therefore conducted a meta-analysis (30) to ascertain the strength of the association between acculturation and BP and to examine the influence of contextual factors, such as world region, gender, age, etc., in moderating that association. Furthermore, because some previous studies have indicated that the stress of cultural change appears to be a more central to acculturation effects than changes in health behaviors, we also desired to test that hypothesis through evaluation of relevant variables such as length of residence in the new culture.

\section{Method}

\section{Literature Search}

To identify published and unpublished studies examining the association between acculturation and BP, we used three techniques. First, we conducted searches with several electronic databases: Dissertation Abstracts, HealthSTAR, Medline, Mental Health Abstracts, PsycINFO, Social Sciences Abstracts, and Sociological Abstracts via SocioFile. To capture the broadest possible sample of relevant articles, we used multiple search terms, including the phrase “blood pressure” crossed with a series of search words related to acculturation (all words beginning with the roots accultur, migrat, immigra, modern, industrial, and urban). To reduce inadvertent omissions, databases yielding the most citations (Medline, PsycINFO) were searched two additional times. Second, we manually examined the reference sections of past reviews and of studies meeting the inclusion criteria for articles not identified in the database searches. 
Finally, we sent solicitation letters to authors who had published three or more articles on the topic.

We included in the meta-analysis studies written in English that provided quantitative data on individuals’ blood pressure as a function of acculturation to a Western society. We defined acculturation as changes in behavior indicating adaptation to Western society (e.g., acquisition of a Western language) or changes in residence that resulted in increased exposure to Western society, including industrialization, modernization, and urbanization. Qualitative research and single-case designs were excluded from the meta-analysis, but both correlational and comparison group designs were included.

\section{Data Coding}

To decrease the likelihood of human error in coding data, a team of two raters coded each article. Team members helped one another to verify the accuracy of coding and data entry. Subsequently each article was independently coded by a different two-rater team.

Coders extracted several objectively verifiable characteristics of the studies: 1) the number of participants and their composition by gender, ethnicity, and age if reported; 2) participants’ medical/health variables, including average systolic and diastolic blood pressure, blood serum cholesterol levels, and body mass index (BMI); 3) the location of data collection if reported (world region, urban vs. rural); and 4) the type and length of acculturation experienced by participants in the study. In addition, coders evaluated the methodological rigor of the research studies by considering the research procedures and design (i.e., appropriate control groups, adequate measurement and analyses, minimal apparent threats to internal validity). Studies with multiple indicators of methodological rigor were coded "above average" in terms of quality, and studies with multiple methodological limitations were coded as "below average," 
with the remainder coded as “adequate.” Average inter-rater agreement was acceptably high, with Cohen’s kappa being .63 across categorical variables, and intraclass correlation coefficients averaging .81 across continuous variables (31). Discrepancies in the data extracted by the independent teams of coders were resolved by discussion and eventual consensus after computation of inter-rater reliability coefficients.

\section{Computation of Effect Size Estimates}

To enable meta-analytic analyses, the effect sizes extracted from each study were transformed to the metric of the standardized mean difference $(d)(32)$. Data reported in other formats (e.g., Chi-square, correlation, etc.) were transformed to $d$ coefficients using the Metaanalysis Calculator software (33). When no statistic was provided but an analysis was reported as significant, we determined the standardized mean difference corresponding to the reported alpha level (assuming two-tailed alpha $=.05$ unless reported otherwise). When an analysis was reported as non-significant but no additional information was available, we set the effect size coefficient to $d=.00$. These procedures yielded conservative effect size estimates. The direction of effect sizes was coded uniformly, such that positive values indicated higher blood pressure values as a function of exposure/migration to a different culture and negative values indicated lower blood pressure as a function of exposure/migration to a different culture.

\section{Analyses}

To aggregate effect sizes and to estimate the reliability of these aggregates, random effects models were calculated using SPSS macros developed by Lipsey and Wilson (30). Rather than use a fixed effects approach, which assumes that every study evaluates the same exact effect, we analyzed the data using random effects models to account for between-studies 
variation (34-35). This procedure is therefore more appropriate when attempting to generalize the results beyond the studies included in the analyses (35).

Following the computation of the overall magnitude of the association between blood pressure and acculturation, random effects weighted regression models and analyses of variance (ANOVAs) were conducted to examine the influence of potential moderating variables. Such analyses are useful in determining circumstances under which the strength of the results may vary, in order that a more accurate depiction of the association between blood pressure and acculturation is provided. The level of statistical significance was set at $p \leq .01$ in this study.

Results

\section{Descriptive Characteristics}

Statistically non-redundant effect sizes were extracted from 125 studies reported in Table 1 (36-160). Across all studies, data were reported from a total of 223,355 participants. Participant gender and age were reported in 110 (88\%) of the studies, with an average of $42 \%$ of participants in studies being female and with the average age being 38.6 years. The average participant systolic blood pressure (SBP) was 124.7 across 94 studies, and the average participant diastolic blood pressure (DBP) was 77.1 across 93 studies reporting this information. Studies were conducted across the world, with 33 (26\%) in Africa or with African migrants, 29 (23\%) in North America, 23 (18\%) in Polynesia, 12 (10\%) in Asia, 12 (10\%) in Europe, 11 (9\%) in Central or South America, and 5 (4\%) in indeterminate locations.

With regard to research design, the vast majority of studies (77\%) involved the comparison of blood pressure readings across pre-existing groups (e.g., a group that had relocated to a Westernized environment vs. a group that had remained in the original location). The remaining studies involved correlational designs (10\%), longitudinal survey designs (6\%), 
quasi-experimental designs (5\%), or archival designs (2\%). Because of these differences in research designs and because the quality of research is an important factor to consider in metaanalyses (30), we conducted preliminary analyses using coders’ ratings of methodological rigor. Most studies (52\%) demonstrated adequate research methods, with 35\% of studies demonstrating high levels of methodological rigor and 13\% demonstrating methodological limitations. Several authors caution against excluding studies of questionable quality from meta-analyses if there are no differences in study outcomes in comparison with apparently more rigorous studies (161, 162). Therefore, we conducted a random effects weighted analysis of variance of effect sizes across studies of varying methodological rigor. Outcomes did not differ across rated study quality $\left(Q_{(2)}=1.5, p=.46\right.$ for effect sizes with SBP and $Q_{(2)}=.85, p=.65$ for effect sizes with DBP). This finding supported the conclusion that the omnibus analyses should be conducted with the entire set of research studies coded (162).

\section{Omnibus Analysis}

Omnibus effect sizes were evaluated separately for outcomes related to systolic and diastolic blood pressure. Across the 124 studies that evaluated systolic blood pressure (SBP), the random effects weighted average effect size was $d=.28(S E=.023, p<.000001,95 \%$ Confidence interval $=.24$ to .33 ), corresponding to an average difference of $4 \mathrm{~mm} \mathrm{Hg}$ higher SBP between acculturated vs. non-acculturated samples. Across the 114 studies that evaluated diastolic blood pressure (DBP), the random effects weighted average effect size was $d=.30$ (SE $=.025, p<.000001,95 \%$ Confidence interval $=.25$ to .35 ), corresponding to an average difference of 3 mm Hg higher DBP between acculturated vs. non-acculturated samples. Effect sizes ranged from -.75 to 1.83 for SBP and from -.44 to 1.53 for DBP, with the heterogeneity across studies being statistically significant for both evaluations of SBP $\left(Q_{(123)}=2551, p<.001\right)$ 
and $\operatorname{DBP}\left(\mathrm{Q}_{(113)}=2415, p<.001\right)$, suggesting that systematic effect size variability was unaccounted for. We therefore conducted additional analyses to determine the extent to which the variability in the effect sizes was moderated by other variables.

\section{Publication Bias}

As a first step, we conducted analyses to evaluate the possibility that the results were moderated by the publication status of the research manuscript. These analyses were essential because of 1) the likelihood for meta-analyses to include greater numbers of published than unpublished studies and 2) the likelihood for published studies to have effect sizes of greater magnitude than those of unpublished studies. Together these two trends can result in publication bias in the results of a meta-analysis.

To assess for the possibility of publication bias, we conducted three analyses. First, we plotted a "funnel graph" (163), which is a scatterplot of the effect sizes versus the total sample size of the study. The data obtained from this meta-analysis did conform to the expected inverse funnel shape, indicating that there were apparently few missing studies that would have changed the results. Second, we calculated a fail-safe N (163), which is the theoretical number of unpublished studies with effect sizes averaging zero (no effect) that would need to be located in order to reduce the overall magnitude of the results obtained to zero. Based on this calculation, at least 350 additional studies averaging $d=0$ would need to be found to render negligible the results of the present meta-analysis. Third, we employed the "trim and fill” methodology described by Duval and Tweedie $(164,165)$ to estimate the number of studies missing due to publication bias and to recalculate the weighted mean effect sizes accordingly. Using formulae provided by Jennions and Moller (166), the recalculated random effects weighted mean effect size for SBP was $d=.26(p<.00001,95 \%$ Confidence interval $=.21, .31)$ and for DBP it was $d$ 
$=.28(p<.00001,95 \%$ Confidence interval $=.23, .33)$. Based on these three analyses, publication bias seems an unlikely threat to the results.

\section{Moderation By Participant and Study Characteristics}

To determine whether differences in the gender composition or average age of the participants accounted for significant between-studies variance, we correlated the percentage of females and the average participant age with the corresponding average effect size. Across the studies that examined SBP, the random effects weighted correlation with the percentage of female participants was $-.19(p=.0034)$ and $.07(\mathrm{p}=.32)$ with average participant age. Across studies that evaluated DBP, the random effects weighted correlation with percent females was $.21(p=.0026)$ and $.02(\mathrm{p}=.76)$ with average age. Therefore, the results of this meta-analysis were moderated by the gender composition of the sample but not by average participant age. Studies with higher proportions of male participants typically had stronger associations between acculturation and BP.

Several of the studies investigated in this meta-analysis reported average values for participants' health/medical data. Of the kinds of data reported, only body mass index (BMI) and blood serum cholesterol were reported across at least 12 studies (10\% of the total number). Random effects weighted correlations between the effect sizes obtained and participants' average BMI values (across 48 studies reporting these data) did not reach statistical significance for neither SBP $(r=.06 ; p=.72)$ nor DBP $(r=-.05 ; p=.66)$. Similarly, the random effects weighted correlations obtained with blood serum cholesterol levels (across 20 studies) were also not statistically significant for the analyses involving neither SBP $(r=.01 ; p=.99)$ nor DBP $(r=$ $.05 ; p=.42)$. 
Studies typically evaluated the differences in blood pressure associated with one of three kinds of acculturation: 1) adaptation to Westernization/industrialization, 2) migration to a more industrial environment, and 3) adaptation to a host culture. We therefore analyzed the differences among these three different ways of operationalizing acculturation. As can be seen in Table 2 and Figure 1, those studies that specifically evaluated migration to a more industrial environment yielded a significantly higher average effect size than studies that evaluated other kinds of acculturation.

A related analysis was conducted to determine if the urban/rural composition of the research sample moderated the results. Given the salience of migration demonstrated in the preceding analysis, populations were categorized into four groups: 1) extant rural sample, 2) extant urban sample, 3) combined urban and rural samples, and 4) migrants from rural to urban locations. Studies involving participants who were migrants from rural to urban settings had higher SBP and DBP effect sizes than the other groups, with the difference reaching statistical significance for DBP effect sizes (Table 2).

Length of residence in the new culture was also considered as a possible moderating variable. Length of residence was categorized as being 0-3 months, 3 months to 3 years, 3 to 15 years, and greater than 15 years, with a separate category for studies involving participants who were born in the host culture (and had never migrated). The results indicate a clear trend for effect sizes that were large upon initial entry in a new culture to decrease over time, with effect sizes among residents of over 15 years being no different than those of participants from a minority ethnic/racial group who had been born in the host culture (Table 2 and Figure 2). Finally, to determine whether the geographic location of the research sample accounted for significant between-studies variance, we compared studies conducted with participants from 
Africa, Asia, Central or South America, Europe, Middle-East, North America, and Polynesia. Studies from all regions of the world yielded effect sizes greater than zero, indicating that the acculturation effects are universal; however, among the DBP effect sizes, studies conducted with participants from the Middle-East had higher average random weighted effect sizes ( $d=.49$ ) than studies with participants from other regions of the world (Table 2). This finding is likely due to the fact that 6 of the 10 studies from the Middle-East evaluated recent migrants from Ethiopia to Israel, with high levels of impoverishment among the migrants and with correspondingly large gaps between their previous circumstances and the new host society.

\section{Discussion}

The main purpose of this meta-analysis was to ascertain the magnitude of the association between blood pressure and acculturation to Western societies. In the omnibus analysis, it was found that increased acculturation was related to increased systolic $(d=.28)$ and diastolic $(d=$ .30) blood pressure. On average, more acculturated individuals had $4 \mathrm{~mm}$ Hg higher SBP and 3 mm Hg higher DBP than less acculturated individuals. The magnitude of the association between blood pressure and acculturation is comparable to that of established risk factors for increased blood pressure such as body weight, level of physical activity, and work stress. Reducing body weight has been associated with about a $5 \mathrm{~mm}$ Hg reduction in SBP and $4 \mathrm{~mm}$ Hg reduction in DBP, while increasing physical activity has been associated with about a $5 \mathrm{~mm}$ Hg reduction in SBP and $5 \mathrm{~mm}$ Hg reduction in DBP (22, 167-168). With the extensive attention given to reducing weight and increasing physical activity as means to reduce blood pressure, it seems clear that issues relevant to acculturation warrant further investigation.

A secondary purpose of this meta-analysis was to examine whether the stress of cultural change contributed more to changes in BP than changes in health behavior. Two variables 
related to obesity and physical activity that were occasionally measured in the acculturation literature were body mass index (BMI) and cholesterol. Interestingly, neither BMI nor cholesterol was related to the acculturation effect. In fact, the largest effect sizes occur at the time of initial contact with the new culture and then drop precipitously within the first three years of acculturation, whereas the effect of acculturation on BP was nonsignificant for those in contact with the new culture for 15 years or more (Figure 2). In other words, the majority of the acculturation effect appears to happen within the first three years of interaction with the new culture. Given that BMI and cholesterol are not associated with the differences between blood pressures of acculturated and non-acculturated groups and that these differences decrease rapidly following the first few years of cultural contact, it is possible that the distress of cultural change plays a more important role in the acculturation effect than changes in diet or physical activity. This conclusion is consistent with several studies that have found a significant acculturation effect on BP even after controlling for health related variables such as BMI and cholesterol (8-9, 23).

Two additional pieces of evidence provide support for the importance of stress in acculturation. First, relocation from rural to urban areas was associated with higher effect sizes than were other aspects of acculturation (e.g., language acquisition). Rural groups tend to live more traditional lifestyles based on communal effort, extended family networks, and higher social support—all of which can act as buffers against stress $(13,17)$. In contrast, urban groups tend to have lifestyles based on individualistic values and economic competition, with smaller family networks and less social support—which factors are associated with higher levels of distress. Relocating from rural to urban settings can result in distress as migrants try to adapt to a lifestyle that involves more competition and less social support. 
Second, the effect of acculturation to Western societies upon BP was more pronounced in men than in women. Men are usually more negatively affected by acculturation because they are more likely to be in the workplace, which is associated with increased demands and with more constant exposure to the dominant culture (13). Women migrants are more likely to remain in the home, interacting with a network of culturally similar women. By contrast, male migrants tend to have smaller social networks, resulting in fewer social resources to cope with life stressors.

Future Directions for Acculturation Research and Limitations of Current Studies

Although it appears that the distress associated with cultural relocation has a major impact on the effect of acculturation on blood pressure, few studies have directly examined this phenomenon. The majority of research studies have focused on the measurement of physiological variables, such as BMI or cholesterol. Ironically, researchers have typically done a poor job at defining and evaluating the kind of acculturation that is occurring, for example, only noting that people have migrated or that an area has become industrialized. Future studies would benefit by more clearly defining acculturation and by using better methods to measure acculturation.

Berry (169) has proposed a comprehensive conceptual framework for defining acculturation based on two key axes. The first axis is the degree to which those acculturating wish to maintain their cultural identity and the second axis is the degree to which they wish to interact with those in the new culture. The interaction of these two axes results in four major types of acculturation: integration, assimilation, separation, and marginalization. Integration is the desire to maintain one's original cultural identity as well as seeking to interact with the new culture. Assimilation is leaving behind one's original cultural identity while seeking interaction 
with the new culture. Separation involves maintaining one's original cultural identity while avoiding interaction with the new culture. Marginalization results when there is no desire to maintain cultural identity or to interact with the new culture. It has been hypothesized that integration is the most adaptive and healthiest type of acculturation and future research should be conducted to see if that is indeed the case with respect to changes in BP.

Berry (169) also notes that the stress of acculturation can depend upon a variety of factors in addition to type of acculturation, including characteristics of the new country as well as the country of origin, and demographic, social, and psychological characteristics of those acculturating. Therefore, in regards to the measurement of acculturation, greater care needs to be taken that the measures used accurately assess core constructs of the acculturation process and that the measures can adequately distinguish between cultures (170-171).

Another major limitation in the literature is that the majority of studies have been crosssectional. Scant data are available on how acculturation and BP covary over time, making it difficult to make any firm statements about causation. Future studies would benefit from using controlled, longitudinal designs that carefully assess both cultural and psychosocial changes, as well as physiological changes. In fact, in this meta-analysis more rigorously conducted studies had larger effect sizes for acculturation.

Although it is known that people in non-Western cultures tend to be more collectivistic and group oriented than those from Western cultures (17), no studies have examined how changes in cultural values or cultural orientation (such as individualism versus collectivism) are related to changes in blood pressure. Some researchers have suggested that more collectivistic cultures have better health because increased social support acts as a buffer against stress (18). It is also possible that the increased achievement orientation and competition found in Western 
society will be particularly stressful for immigrants as they attempt to adapt to a new way of life (17). Given that the stress of cultural change appears to be a key factor in acculturation, the assessment of cultural change may be the most fruitful line of research in future acculturation studies.

Studying psychosocial stressors common in Western societies may also be a worthwhile endeavor. Stressors such as social isolation, work stress, and socioeconomic stress are less prevalent in non-Western societies (13); thus they may be particularly stressful for immigrants who have little experience with them. Immigrants tend to have lower SES, greater work related stress, and smaller social networks than those in the majority culture.

Utilizing more accurate methods to assess BP may also improve the quality of the findings obtained in acculturation studies. A large majority of studies of acculturation have used only clinic BP assessment techniques, often relying on only one or two clinic BP measurements. More advanced BP assessment techniques, such as ambulatory blood pressure measurement, would improve the quality and reliability of the data obtained. Additionally, impedance cardiography would make it possible to examine the underlying hemodynamics associated with acculturation. Previous studies have found that a shift in hemodynamics from BP driven by cardiac output to BP driven by increased systemic vascular resistance underlies the development of high blood pressure (172-173). It would be interesting to see if acculturation is associated with increased systemic vascular resistance over time. Another factor implicated in the development of high blood pressure is higher levels of catecholamines, particularly norepinephrine. The Timio et al. study (174) found that norepinephrine was higher among those more acculturated.

Conclusions 
Acculturation to Western lifestyle is associated with higher BP. BMI and cholesterol are not associated with the acculturation effect, but the stress of cultural change appears to be a major component. Although it appears that acculturation to Western society is a risk factor for increased blood pressure, the processes through which this occurs are still unclear. Future studies would benefit from doing more carefully controlled longitudinal studies of the effects of acculturation on changes in stress, lifestyle, and cultural values. 


\section{References}

1. Donnison CP, Lond BS. Blood pressure in the African native. Lancet 1929;1:6-7.

2. Kaminer B, Lutz WP. Blood pressure in Bushmen of the Kalahari. Circulation 1960;22:289-

95.

3. Lowenstein FW. Blood pressure in relation to age and sex in the tropics and subtropics. Lancet 1961;1:389-92.

4. Ordman B. A review of the incidence of hypertension in the non-European races. Clinical Proceedings 1948;7:183-210.

5. Shaper AG. Cardiovascular disease in the tropics - III, blood pressure and hypertension. BMJ $1972 ; 3: 805-7$.

6. Marmot MG. Geography of blood pressure and hypertension. Br Med Bull 1984:40:380-6.

7. Cooper R, Rotimi C, Ataman S, McGee D, Osotimehin B, Kadiri S, Muna W, Kingue S, Fraser H, Forrester T, Bennett F, Wilks R. Am J Public Health 1997;87:160-8.

8. Marmot MG, Syme SL. Acculturation and coronary heart disease in Japanese-Americans. Am J Epidemiol 1976;104:225-47.

9. Shaper AG, Leonard PJ, Jones KW, Jones M. Environmental effects on the body build, blood pressure and blood chemistry of nomadic warriors serving in the army of Kenya. East Afr Med J 1969;46:282-9.

10. Wilson TW, Hollifield LR, Grim CE. Systolic blood pressure levels in Black populations in sub-Sahara Africa, the West Indies, and the United States: A meta-analysis. Hypertension 1991;18:87-91.

11. Grossman E, Rosenthal T. Effect of urbanization on blood pressure in Ethiopian immigrants. J Hum Hypertens 1993;7:559-61. 
12. Ostfeld AM, D’Atri DA. Rapid sociocultural change and high blood pressure. Adv Psychosom Med 1977;9:20-37.

13. Waldron I, Nowotarski M, Freimer M, Henry JP, Post N, Witten C. Cross-cultural variation in blood pressure: a quantitative analysis of the relationships of blood pressure to cultural characteristics, salt consumption and body weight. Soc Sci Med 1982;16:419-30.

14. Gupta R, Al-Odat NA, Gupta VP. Hypertension epidemiology in India: meta-analysis of 50 year prevalence rates and blood pressure trends. J Hum Hypertens 1996;10:465-72.

15. Lore W. Epidemiology of cardiovascular diseases in Africa with special reference to Kenya: an overview. East Afr Med J 1993;70:357-61.

16. Steptoe A. Psychosocial factors in the development of hypertension. Ann Med 2000;32:371-

5.

17. Triandis H. Individualism and collectivism. Boulder, CO: Westview Press; 1995.

18. Adler NE, Boyce T, Chesney MA, Cohen S, Folkman S, Kahn RL, Syme SL. Socioeconomic status and health: The challenge of the gradient. Am Psychol 1994;49:15-24.

19. Marmot MG, Smith GD, Stansfeld S, Patel C, North F, Head J, White I, Brunner E, Feeney A. Health inequalities among British civil servants: the Whitehall II study. Lancet 1991;337:1387-1393.

20. Cardiovascular risk factors in Mexican American adults: A transcultural analysis of NHANES III, 1988-1994. Am J Public Health 1999;89:723-30.

21. Stern MP. Do Mexican Americans really have low rates of cardiovascular disease? Prev Med 1999;29:S90-5.

22. Geleijnse JM, Kok FJ, Grobbee DE. Impact of dietary and lifestyle factors on the prevalence of hypertension in Western populations. Eur J Public Health 2004;14:235-9. 
23. Timio M, Verdecchia P, Venanzi S, Gentili S, Ronconi M, Francucci B, Montanari M, Bichisao E. Age and blood pressure changes. A 20-year follow-up study in nuns in a secluded order. Hypertension 1988;12:457-61.

24. Hollenberg NK, Martinez G, McCullough ME, Meinking T, Passan D, Preston M, Rivera A, Taplin D, Vicaria-Clement M. Aging, acculturation, salt intake, and hypertension in the Kuna of Panama. Hypertension 1997;29:171-6.

25. Schnall PL, Schwartz JE, Landbergis PA, Warren K, Pickering TG. A longitudinal study of job strain and ambulatory blood pressure: Results from a three-year follow-up. Psychosom Med 1998;60:697-706.

26. Steptoe A, Brydon L, Kunz-Ebrecht S. Changes in financial strain over three years, ambulatory blood pressure, and cortisol responses to awakening. Psychosom Med 2005;67:2817.

27. Baker B, Paquette M, Szalai JP, Driver H, Perger T, Helmers K, O’Kelly B, Tobe S. The influence of marital adjustment on 3-year left ventricular mass and ambulatory blood pressure in mild hypertension. Arch Intern Med 2000;16:3453-8.

28. Bursztyn M, Raz I. Blood pressure and insulin in Ethiopian immigrants: longitudinal study. J Hum Hypertens 1995;9:245-8.

29. Green MS, Etzion T, Jucha E. Blood pressure and serum cholesterol among male Ethiopian immigrants compared to other Israelis. J Epidemiol Comm Health 1991;45:281-6.

30. Lipsey MW, Wilson DB. Practical meta-analysis. Thousand Oaks, CA: Sage; 2001.

31. Shrout PE, Fleiss JL. Intraclass correlations: uses in assessing rater reliability. Psych Bull 1979; 86:420-428. 
32. Cohen J. Statistical power analysis for the behavioral sciences (2nd ed.). Hillsdale, NJ: Earlbaum; 1988.

33. Lyons L. The meta-analysis calculator [Computer software]. Manassas, VA: Author; 1996 34. Hedges LV, Vevea JL. Fixed- and random-effects models in meta-analysis. Psych Methods $1998 ; 3: 486-504$.

35. Mosteller F, Colditz GA. Understanding research synthesis (meta-analysis). Ann Rev Pub Health 1996;17:1-23.

36. Abdul-Rahim HF, Husseini A, Bjertness E, Giacaman R, Gordon NH, Jervell J. The metabolic syndrome in the West Bank population: an urban-rural comparison. Diabetes Care $2001 ; 24: 275-9$.

37. Akinkugbe OO, Ojo OA. Arterial pressures in rural and urban populations in Nigeria. $\mathrm{Br}$ Med J 1969;2:222-4.

38. Baker PT. Un studio de los aspectos biologicos y socials de la migracion Andina. Arch Biol Andina 1977;7:63-82.

39. Beaglehole R, Eyles E, Salmond C, Prior I. Blood pressure in Tokelauan children in two contrasting environment. Am J Epidemiol 1978;108:283-7.

40. Beaglehole R, Eyles E, Prior I. Blood pressure and migration in children. Int J Epidemiol 1979;8:5-10.

41. Beaglehole R, Salmond CE, Hooper A, Huntsman J, Stanhope JM, Cassel JC, Prior IA. Blood pressure and social interaction in Tokelauan migrants in New Zealand. J Chron Dis 1977;30:803-12.

42. Beiser M, Collomb H, Ravel JL, Nafziger CJ. Systemic blood pressure studies among the Serer of Senegal. J Chron Dis 1976;29:371-80. 
43. Beiser M. Coping with past and future: a study of adaptation to social change in West Africa. J Operational Psychiatry 1980;11:140-55.

44. Benson H, Costas RJr, Garcia-Palmieri MR, Feliberti M, Aixala R, Blanton JH, Colon AA. Coronary heart disease risk factors: a comparison of two Puerto Rican populations. Am J Public Health 1966;56:1057-60.

45. Bjerregaard P, Jorgensen ME, Lumholt P, Mosgaard L, Borch-Johnsen. Higher blood pressure among Inuit migrants in Denmark than among the Inuit in Greenland. J Epidemiol Community Health 2002;56:279-84.

46. Bongard S, Pogge SF, Arslaner H, Rohrmann S, Hodapp V. Acculturation and cardiovascular reactivity of second-generation Turkish migrants in Germany. J Psychosom Res 2002;53:795803.

47. Bose J, Mascie-Taylor CGN. Conicity index and waist-hip ratio and their relationship with total cholesterol and blood pressure in middle-aged European and migrant Pakistani men. Ann Hum Biol 1998;25:11-6.

48. Brown DE, James GD. Physiological stress responses in Filipino-American immigrant nurses: the effects of residence time, life-style, and job strain. Psychosom Med 2000;62:394-400. 49. Brunner D, Meshulam N, Altman S, Bearman JE, Loebl K, Wendkos ME. Physiologic and anthropometric parameters related to coronary risk factors in Yemenite Jews living different time spans in Israel. J Chron Dis 1971;24:383-92.

50. Bursztyn M, Raz I. Blood pressure, glucose, insulin and lipids of young Ethiopian recent immigrants to Israel and in those resident for 2 years. J Hypertens 1993;11:455-9.

51. Bursztyn M, Raz I. Prediction of hypertension by the insulinogenic index in young Ethiopian immigrants. J Hypertens 1995;13:57-61. 
52. Bursztyn M, Raz I. Blood pressure and insulin in Ethiopian immigrants: longitudinal study. J Hum Hypertens 1995;9:245-8.

53. Mancilha-Carvalho JJ, Carvalho JV, Costa Lima JA, Sousa e Silva NA. Ausencia de fatores de risco de doenca coronaria em indios yanomami e influencia da aculturacao na pressao arterial. Arq Bras Cardiol 1992;59:275-83.

54. Chase HP, Garg SK, Icaza G, Carmain JA, Walravens CF, Marshall G. 24-h ambulatory blood pressure monitoring in healthy young adult Anglo, Hispanic, and African-American subjects. Am J Hypertens 1997;10:18-23.

55. Cruz-Coke R. Correlation between prevalence of hypertension and degree of acculturation. J Hypertens 1987;5:47-50.

56. Cruz-Coke R, De La Barrera C. Presion arterial en natives de Isla de Pascua. Rev Med Chile 1981;109:99-102.

57. Cruz-Coke R, Etcheverry R, Nagel R. Influence of migration on blood-pressure of Easter Islanders. Lancet 1964;March:697-9.

58. Dachman WD, Adubofour KO, Kapoor C, Rackleff D. Variability in vascular responsiveness between Mexican-Americans and White Americans. J Hum Hypertens 1998;12:167-71. 59. Dallo FJ, James SA. Acculturation and blood pressure in a community-based sample of Chaldean-American women. J Immigrant Health 2000;2:145-53.

60. Dash SC, Sundaram KR, Swain PK. Blood pressure profile, urinary sodium and body weight in the 'Oraon’ rural and urban tribal community. J Assoc Physicians India 1994;42:878-80. 61. DeStefano F, Coulehan JL, Wiant MK. Blood pressure survey on the Navajo Indian reservation. Am J Epidemiol 1979;109:335-45. 
62. Dressler WW, Balieiro MC, Ernesto dos Santos J. The cultural construction of social support in Brazil: associations with health outcomes. Cult Med Psychiatry 1997;21:303-35.

63. Dressler WW, Bindon JR. The health consequences of cultural consonance: cultural dimensions of lifestyle, social support, and arterial blood pressure in an African American community. Am Anthropologist 2000;102:244-60.

64. Dressler WW, Bindon JR, Gilliland MJ. Sociocultural and behavioral influences on health status among the Mississippi Choctaw. Med Anthropol 1996;17:165-80.

65. Dressler WW, Mata A, Chavez A, Viteri FE. Arterial blood pressure and individual modernization in a Mexican community. Soc Sci Med 1987;24:679-87.

66. Elder JP, Woodruff SI, Candelaria J, Goldbeck AL, Alvarez JL, Criqui JH, Norquist CD, Rupp JW. Socioeconomic indicators related to cardiovascular disease risk factors in Hispanics. Am J Health Behav 1998;22:172-85.

67. Elford J, Phillips A, Thomson AG, Shaper AG. Migration and geographic variations in blood pressure in Britain. BMJ 1990;300:291-5.

68. Espino DV, Maldonado D. Hypertension and acculturation in elderly Mexican Americans: results from 1982-84 Hispanic HANES. J Gerontol Med Sci 1990;45:M209-13. 69. Fleming-Moran M, Santos RV, Coimbra, CEA Jr. Blood pressure levels of the Suruf and Zoro Indians of the Brazilian Amazon: group- and sex-specific effects resulting from body composition, health status, and age. Hum Biol 1991;63:835-61.

70. Florey CV, Cuadrado RR. Blood pressure in native Cape Verdeans and in Cape Verdean immigrants and their descendants living in New England. Hum Biol 1968;40:189-211. 71. Fulmer HS, Roberts RW. Coronary heart disease among the Navajo Indians. Ann Inter Med $1963 ; 59: 740-64$. 
72. Gampel B, Slome C, Scotch N, Abramson JH. Urbanization and hypertension among zulu adults. J Chron Dis 1962;15:67-70.

73. Garcia-Palmieri MR, Costas R, Cruz-Vidal M, Cortes Alicea M, Colon AA, Feliberti M, Ayala AM, Patterne D, Sobrino R, Torres R, Nazario E. Risk factors and prevalence of coronary heart disease in Puerto Rico. Circulation 1970;42:541-9.

74. Gilberts ECAM, Arnold MJCWJ, Grobee DE. Hypertension and determinants of blood pressure with special reference to socioeconomic status in a rural south Indian community. J Epidemiol Community Health 1994;48:258-61.

75. Goldbourt U, Khoury M, Landau E, Reisin LH, Rubinstein A. blood pressure in Ethiopian immigrants: relationship to age and anthropometric factors, and changes during their first year in Israel. Isr J Med Sci 1991;27:264-7.

76. Goslar PW, Macera CA, Castellanos LG, Hussey JR, Sy FS, Sharpe PA. Blood pressure in Hispanic women: the role of diet, acculturation, and physical activity. Ethn Dis 1997;7:106-13. 77. Green MS, Peled I. Differences in the prevalence of hypertension by ethnic origin and age at immigration in a cohort of 5,146 Israelis. Am J Epidemiol 1992;135:1237-50.

78. Grossman E, Rosenthal T. Effect of urbanization on blood pressure in Ethiopian immigrants. J Hum Hypertens 1993;7:559-61.

79. Guerrero-Romero F, Rodriguez-Moran M, Sandoval-Herrrera F, Alvarado-Ruiz R. Prevalence of hypertension in indigenous inhabitants of traditional communities from the north of Mexico. J Hum Hypertens 2000;14:555-9.

80. Hackenberg RA, Hackenberg BH, Magalit HF, Cabral EI, Guzman SV. Migration, modernization, and hypertension: blood pressure levels in four Philippine communities. Med Anthropol 1983;4:45-71. 
81. Haffner S, Villalpando CG, Hazuda HP, Valdez R, Mykkanen L, Stern M. Prevalence of hypertension in Mexico City and san Antonio, Texas. Circulation 1994;90:1542-9.

82. Haffner SM, Mitchell BD, Stern MP, Hazuda HP, Patterson JK. Decreased prevalence of hypertension in Mexican-Americans. Hypertension 1990;16:225-32.

83. Haffner SM, Mitchell BD, Valdez RA, Hazuda RA, Hazuda HP, Morales PA, Stern MP. Eight-year incidence of hypertension in Mexican-Americans and Non-Hispanic Whites. Am J Hypertens 1992;5:147-53.

84. Hanna JM, Baker PT. Biocultural correlates to the blood pressure of Samoan migrants in Hawaii. Hum Biol 1979;51:481-97.

85. Hanna JM. Psychosocial factors in blood pressure variation: a comparative study of young Samoans. Soc Biol 1996;43:169-90.

86. Hansen H. Acculturation, social support, and hypertension in elderly Mexican-American women [Ph.D. Psychology Dissertation]. Palo Alto CA: Pacific Graduate School of Psychology; 1996.

87. Harland JO, Unwin N, Bhopal RS, White M, Watson B, Laker M, Alberti KG. Low levels of cardiovascular risk factors and coronary heart disease in a UK Chinese population. J Epidemiol Community Health 1997;51:636-42.

88. Hawthorne VM, Gillis CR, Lorimer AR, Calvert FR, Walker TJ. Blood pressure in a Scottish island community. Br Med J 1969;4:651-4.

89. Hazuda HP. Hypertension in the San Antonio heart study and the Mexico City diabetes study: sociocultural correlates. Public Health Rep 1996;3:18-21.

90. He J, Tell GS, Tang YC, Mo PS, He GQ. Effect of migration on blood pressure: the Yi people study. Epidemiology 1991;2:88-97. 
91. Hyman DJ, Ogbonnaya K, Pavlik VN, Poston WSC, Ho K. Lower hypertension prevalence in first-generation African immigrants compared to US-born African Americans. Ethn Dis 2000;10:343-49.

92. James GD. The relation of norepinephrine to blood pressure is independent of acculturation in Western Samoan men. Am J Hypertens 1989;2:471-3.

93. Janes CR, Pawson IG. Migration and biocultural adaptation: Samoans in California. Soc Sci Med 1986;22:821-34.

94. Jorgenson RJ, Bolling DR, Yoder OC, Murphy EA. Blood pressure studies in the Amish. Johns Hopkins Med J 1972;131:329-50.

95. Joseph JG, Prior IAM, Salmond CE, Stanley D. Elevation of systolic and diastolic blood pressure associated with migration: the Tokelau island migrant study. J Chron Dis 1983;36:507516.

96. Kaminer B, Lutz WP. Blood pressure in Bushmen of the Kalahari Desert. Circulation 1960;22:289-95.

97. Kaufman JS, Owoaje EE, James SA, Rotimi CN, Cooper RS. Determinants of hypertension in West Africa: contribution of anthropometric and dietary factors to urban-rural and socioeconomic gradients. Am J Epidemiol 1996;143:1203-18.

98. Kaufman JS, Owoaje EE, Rotimi CN, Cooper RS. Blood pressure change in Africa: case study from Nigeria. Hum Biol 1999;71:641-57.

99. Keil JE, Britt RP, Weinrich MC, Hollis Y, Keil BW. Hypertension in Punjabi females: comparison between migrants to London and natives in India. Hum Biol 1980;52:423-33. 100. Keil JE, Cowan B. Prevalence of hypertension in females of Punjab State, India: relationships with age, residence, heart rate, occupation, and obesity. Hum Biol 1977;49:641-50. 
101. Kim MT, Kim KB, Juon H, Hill MN. Prevalence and factors associated with high blood pressure in Korean Americans. Ethn Dis 2000;10:364-74.

102. Klag MJ, He J, Coresh J, Whelton PK, Chen YJ, Mo JP, Qian MC, Mo PS, He GQ. The contribution of urinary cations to the blood pressure differences associated with migration. Am J Epidemiol 1995;142:295-303.

103. Kunitz SJ, Levy JE. The prevalence of hypertension among elderly Navajos: a test of the acculturative stress hypothesis. Cult Med Psychiatry 1986;10:97-121.

104. Kusuma YS, Babu BV, Naidu JM. Blood pressure levels among cross-cultural populations of Visakhapatnam district, Andhra Pradesh, India. Ann Hum Biol 2002;5:502-512.

105. Labarthe D, Reed D, Brody J, Stallones R. Health effects of modernization in Palau. Am J Epidemiol 1973;98:161-74.

106. Lewis E Jr. Change and hypertension in the population of Marakei Atoll, Kiribati [Ph.D. Philosophy Dissertation]. Tucson AZ: Department of Anthropology. Graduate College of the University of Arizona; 1981.

107. Lizarzaburu JL, Palinkas LA. Immigration, acculturation, and risk factors for obesity and cardiovascular disease: a comparison between Latinos of Peruvian descent in Peru and in the United States. Ethn Dis 2002;12:342-52.

108. Lubree HG, Rege SS, Bhat DS, Raut KN, Panchnadikar A, Joglekar CV, Yajnik CS, Shetty P, Yudkin J. Body fat and cardiovascular risk factors in Indian men in three geographical locations. Food Nutr Bull 2002;23:146-9.

109. Malan NT, Van der Merwe JS, Huisman HW, Kruger A, Eloff FC, Pretorius PJ, Laubscher PJ. A comparison of cardiovascular reactivity of rural Blacks, urban Blacks and Whites. Stress Med 1992;8:241-6. 
110. Mugamer IT, Zayat AS, Hossain MM, Pugh RNH. Diabetes, obesity and hypertension in urban and rural people of Bedouin origin in the United Arab Emirates. J Trop Med Hyg 1995;98:407-15.

111. Mukhopadhyay B, Mukhopadhyay S. Blood pressure and its biocultural correlates among the Lepchas of Sikkim, India: a microlevel epidemiological study. Coll Antropol 2001;25:97110.

112. Murphy JK, McGarvey ST. Modernization in the Samoas and children’s reactivity: a pilot study. Psychosom Med 1994;56:395-400.

113. Nadim A, Amini H, Malek-Afzali H. Blood pressure and rural-urban migration in Iran. Int J Epidemiol 1978;7:131-8.

114. Nirmala A. Age variation in blood pressure: effect of sex and urbanization in a genetically homogeneous caste population of Andhra Pradesh. Am J Hum Biol 2001;13:744-52.

115. Norman-Taylor W, Rees WH. Blood pressures in three new Hebrides communities. Brit J Prev Soc Med 1963;17:141-4.

116. Okosun IS, Forrester TE, Rotimi CN, Osotimehin BO, Muna WF, Cooper RS. Abdominal adiposity in six populations of West African descent: prevalence and population attributable fraction of hypertension. Obes Res 1999;7:453-62.

117. Osei K, Schuster DP. Effects of race and ethnicity on insulin sensitivity, blood pressure, and heart rate in three ethnic populations: comparative studies in African-Americans, African immigrants (Ghanaians), and white Americans using ambulatory blood pressure monitoring. Am J Hypertens 1996;9:1157-64.

118. Padmavati S, Gupta S. Blood pressure studies in rural and urban groups in Delhi. Circulation 1959;19:395-405. 
119. Page LB, Damon A, Moellering RC Jr. Antecedents of cardiovascular disease in six Solomon Islands societies. Circulation 1974;49:1132-46.

120. Patrick RC, Prior IAM, Smith JC, Smith AH. Relationship between blood pressure and modernity among Ponapeans. Int J Epidemiol 1983;12:36-44.

121. Pavan L, Casiglia E, Pauletto P, Batista SL, Ginocchio G, Kwankam MM, Biasin R, Mazza A, Puato M, Russo E, Pessina AC. Blood pressure, serum cholesterol and nutritional state in Tanzania and in the Amazon: comparison with an Italian population. J Hyperten 1997;15:108390.

122. Poulter N, Khaw KT, Hopwood BE, Mugambi M, Peart WS, Rose G, Sever PS. Blood pressure and associated factors in a rural Kenyan community. Hypertension 1984;6:810-3. 123. Poulter NR, Khaw KT, Hopwood BE, Mugambi M, Peart WS, Rose G, Sever PS. The Kenyan Luo migration study: observations on the initiation of a rise in blood pressure. Br Med J 1990;300:967-72.

124. Poulter NR, Khaw KT, Mugambi M, Peart WS, Rose G, Sever P. Blood pressure patterns in relation to age, weight and urinary electrolytes in three Kenyan communities. Trans R Soc Trop Med Hyg 1985;79:389-92.

125. Prior IA, Evans JG, Harvey HP, Davidson F, Lindsey M. Sodium intake and blood pressure in two Polynesian populations. N Engl J Med 1968;279:515-20.

126. Proctor MH, Moore LL, Singer MR, Hood MY, Nguyen UDT, Ellison RC. Rick profiles for non-communicable diseases in rural and urban schoolchildren in the Republic of Cameroon. Ethn Dis 1996;6:235-43.

127. Reddy KK, Ramachandraiah T, Reddanna P, Thyagaraju K. Serum lipid peroxides and lipids in urban and rural Indian men. Arch Environ Health 1994;49:123-7. 
128. Reed D, Labarthe D, Stallones R. Health effects of westernization and migration among Chamorros. Am J Epidemiol 1970;92:94-112.

129. Rosenthal T, Grossman E, Knecht A, Goldbourt U. Levels and correlates of blood pressure in recent and earlier Ethiopian immigrants to Israel. J Hum Hypertens 1990;4:425-30.

130. Salmond CE, Joseph JG, Prior IA, Stanley DG, Wessen AF. Longitudinal analysis of the relationship between blood pressure and migration: the Tokelau Island migrant study. Am J Epidemiol 1985;122:291-301.

131. Salmond CE, Prior IAM, Wessen AF. Blood pressure patterns and migration: a 14-year cohort study of adult Tokelauans. Am J Epidemiol 1989;130:37-52.

132. Seedat YK, Seedat MA, Hackland DBT. Biosocial factors and hypertension in urban and rural Zulus. S Afr Med J 1982;61:999-1002.

133. Sever PS, Peart WS, Gordon D, Beighton P. Blood-pressure and its correlates in urban and tribal Africa. Lancet 1980:60-4.

134. Shaper AG, Leonard PJ, Jones KW, Jones M. Environmental effects on the body build, blood pressure and blood chemistry of Nomadic warriors serving in the army in Kenya. East Afr Med J 1969;46:282-9.

135. Sherman JJ, McCubbin JA, Matenga J. Effects of parental history of hypertension and urbanization on blood pressure in Zimbabweans. Int J Behav Med 1998;5:48-62.

136. Silman AJ, Evans SJW, Loysen E. Blood pressure and migration: a study of Bengali immigrants in East London. J Epidemiol Community Health 1987;41:152-5.

137. Sobngwi E, Mbanya J, Unwin NC, Kengne AP, Fezeu L, Minkoulou EM, Aspray TJ, Alberti KG. Physical activity and its relationship with obesity, hypertension and diabetes in urban and rural Cameroon. Int J Obes 2002;26:1009-16. 
138. Somova LI, Diarra K, Jacobs TQ. Psychophysiological study of hypertension in Black, Indian and White African students. Stress Med 1995;11:105-11.

139. Taylor R, Bennett P, Uili R, Joffres M, Germain R, Levy S, Zimmet P. Hypertension and indicators of coronary heart disease in Wallis Polynesians: an urban-rural comparison. Eur J Epidemiol 1987;3:247-56.

140. Taylor R, Jalaludin B, Levy S, Montaville B, Gee K, Sladden T. Prevalence of diabetes, hypertension and obesity at different levels of urbanisation in Vanuatu. Med J Aust 1991;155:8690.

141. Taylor R, Zimmet P, Tuomilehto J, Ram P, Hunt D, Sloman G. Blood pressure changes with age in two ethnic groups in Fiji. J Am Coll Nutr 1989;8:335-46.

142. Taylor TR, Harrell JP, Mantenga J, Anderson NG, Adams-Campbell LL. Cardiovascular reactivity in Zimbabwe. Ethn Dis 1999;9:264-71.

143. Timio M, Lippi G, Venanzi S, Gentili S, Quintaliani G, Verdura C, Monarca C, Saronio P, Timio F. Blood pressure trend and cardiovascular events in nuns in a secluded order: a 30-year follow-up study. Blood Press 1997;6:81-7.

144. Tomson Y, Aberg H. Risk factors for cardiovascular disease - a comparison between Swedes and immigrants. Scand J Prim Health Care 1994;12:147-54.

145. Torun B, Stein AD, Schroeder D, Grajeda R, Conlisk A, Rodriguez M, Mendez H, Martorell R. Rural-to-urban migration and cardiovascular disease risk factors in young Guatemalan adults. Int Epidemiol Assoc 2002;31:218-26.

146. Tracy RE, Guileyardo JM. Renovasculopathies of hypertension in Hispanic residents of Dallas, Texas. Arch Med Res 1999;30:40-8. 
147. Tsugane S, Kitagawa Y, Kondo H. ethnic differences in blood pressure level between Japanese school children in Bolivia and Native Bolivians. Int J Epidemiol 1989;18:100-4. 148. Ulman R, Abernethy JD. Blood pressure and length of stay in Australia of Italian immigrants in the Australian national blood pressure study. Int J Epidemiol 1975;4:213-5. 149. van den Hoogen PCW, Feskens EJM, Nagelkerke NJD, Menotti A, Nissinen A, Kromhout D. The relation between blood pressure and motaality due to coronary heart disease among men in different parts of the world. N Engl J Med 2000;342:1-8.

150. van Rooyen JM, Huisman HW, Eloff FC, Laubscher PJ, Malan L, Steyn HS, Malan NT. Cardiovascular reactivity in Black South-African males of different age groups: the influence of urbanization. Ethn Dis 2002;12:69-75.

151. van Rooyen JM, Kruger HS, Huisman HW, Wissing MP, Margetts BM, Venter CS, Vorster HH. An epidemiological study of hypertension and its determinants in a population in transition: the THUSA study. J Hum Hypertens 2000;14:779-87.

152. Villela GJ, Palinkas LA. Sociocultural change and health status among the Seri Indians of Sonora, Mexico. Med Anthropol 2000;19:147-72.

153. Walsh A, Walsh PA. The effects of immigration stigma, and stress on biological effective blood pressure levels. Int Rev Mod Sociology 1986;16:353-66.

154. Walsh A. The prophylactic effect of religion on blood pressure levels among a sample of immigrants. Soc Sci Med 1980;14B:59-63.

155. Ward RH, Chin PG, Prior IA. Tokelau Island migrant study. Hypertension, Suppl I 1980;2:I43-I54.

156. Wilks R, McFarlene-Anderson N, Bennett F, Fraser H, McGee D, Cooper R, Forrester T. Obesity in peoples of the African diaspora. Ciba Found Symp 1996;201:37-48. 
157. Williams R. Health and length of residence among South Asians in Glasgow: a study controlling for age. J Public Health Med 1993;15:52-60.

158. Zerba KE, Friedlaender JS, Sing CF. Heterogeneity of the blood pressure distribution among Solomon Islands societies with increasing acculturation. Am J Phys Anthropol 1990;81:493-511.

159. Zimmet P, Jackson L, Whitehouse S. Blood pressure studies in two Pacific populations with varying degrees of modernization. N Z Med J 1980;91:249-52.

160. Zimmet PZ, Taylor R, Jackson L, Whitehouse SL, Faaivaso S, Ainuu J. Blood pressure studies in rural and urban Western Samoa. Med J Aust 1980;2:202-5.

161. Glass GV, McGaw B, Smith ML. Meta-analysis in social research. Beverly Hills, CA: Sage; 1981.

162. Rosenthal R. Meta-analysis: A review. Psychosom Med 1991;53:247-71.

163. Begg CB. Publication bias. In: Handbook of Research Synthesis. Cooper H, Hedges LV. New York: Russell Sage Foundation; 1994.

164. Duval S, Tweedie R. A non-parametric "trim and fill” method of accounting for publication bias in meta-analysis. J Am Stat Assoc 2000;95:89-98.

165. Duval S, Tweedie R. Trim and fill: A simple funnel-plot based method of testing and adjusting for publication bias in meta-analysis. Biometrics 2000;56:455-463.

166. Jennions MD, Moller AP. Publication bias in ecology and evolution: An empirical assessment using the ‘trim and fill’ method. Bio Rev 2002;77:211-222.

167. Fagard RH. Physical fitness and blood pressure. J Hypertens 1993;11(suppl 5):S47-52. 168. Fagard RH. Physical activity in the prevention and treatment of hypertension in the obese. Med Sci Sport Exerc 1999;31:S624-30. 
169. Berry JW. Psychology of acculturation. In: Berman J, editor. Nebraska Symposium on Motivation, 1989: Cross-cultural perspectives. Lincoln: University of Nebraska Press; 1990. p. 201-34.

170. Hunt HM, Schneider S, Comer B. Should “acculturation” be a variable in health research? A critical review of research on US Hispanics. Soc Sci Med 2004;59:973-986.

171. Salant T, Lauderdale DS. Measuring culture: a critical review of acculturation and health in Asian immigrant populations. Soc Sci Med 2003;57:71-90.

172. Lund-Johansen P. Hemodynamics in essential hypertension at rest and during exercise: a 20-year follow-up study. Ann Clin Res 1988;48:31-8.

173. Folkow B. 'Structural factor’ in primary and secondary hypertension. Hypertension 1990;16:89-101.

174. Timio M, Saronio P, Verdura C, Schiaroli M, Timio F, Monarca C. A link between psychosocial factors and blood pressure trend in women. Physiol Behav 2001;73:59-63. 
Table 1

Descriptions of the 125 Studies Included in the Meta-Analysis.

\begin{tabular}{|c|c|c|c|c|}
\hline \multirow[t]{2}{*}{ Study } & \multirow[t]{2}{*}{ Participants } & \multirow[t]{2}{*}{$\mathrm{N}$} & \multicolumn{2}{|c|}{ Effect Size ( $\underline{\mathrm{d}})$} \\
\hline & & & SBP & DBP \\
\hline Abdul-Rahim 2001 (36) & Urban and Rural & 992 & -0.07 & 0.19 \\
\hline Akinkugbe 1969 (37) & Urban and Rural & 3,058 & 0.28 & 0.28 \\
\hline Baker 1977 (38) & Migrants & 69 & 0.91 & 1.15 \\
\hline Beaglehole 1977 (41) & Migrants & 635 & 0.26 & 0.28 \\
\hline Beaglehole 1978 (39) & Children & 1,117 & 0.27 & NR \\
\hline Beaglehole 1979 (40) & Children & 454 & 0.33 & 0.27 \\
\hline Beiser 1976 (42) & Urban and Rural & 225 & 0.11 & -0.06 \\
\hline Beiser 1980 (43) & Urban and Rural & 456 & 0.00 & 0.00 \\
\hline Benson 1966 (44) & Urban and Rural & 94 & 1.06 & NR \\
\hline Bjerregaard 2002 (45) & Migrants & 3,792 & 0.14 & 0.14 \\
\hline Bongard 2002 (46) & Migrants & 41 & 0.05 & -0.25 \\
\hline Bose 1998 (47) & Migrants & 362 & 0.28 & -0.18 \\
\hline Brown 2000 (48) & Migrants & 31 & 0.32 & 0.12 \\
\hline Brunner 1971 (49) & Migrants & 3,126 & 0.48 & 0.73 \\
\hline Burstyn 1993 (50) & Migrants & 201 & 0.95 & 1.11 \\
\hline Burstyn 1995 (51) & Migrants & 337 & 0.55 & 0.77 \\
\hline Bursztyn 1995 (52) & Migrants & 53 & 0.98 & 0.86 \\
\hline Chasel 1997 (54) & Urban & 118 & 0.38 & 0.26 \\
\hline Cruz-Coke 1964 (57) & Migrants & 179 & NR & 0.25 \\
\hline Cruz-Coke 1981 (56) & Rural & 126 & 0.21 & 0.61 \\
\hline Cruz-coke 1987 (55) & Urban and Rural & 4,195 & 0.35 & NR \\
\hline Dachman 1998 (58) & Urban & 20 & 0.16 & -0.24 \\
\hline Dallo 2000 (59) & Urban & 130 & -0.46 & -0.44 \\
\hline Dash 1994 (60) & Urban and Rural & 3,018 & 0.09 & 0.13 \\
\hline DeStefano 1979 (61) & Rural & 640 & 0.15 & 0.36 \\
\hline Dressler 2000 (63) & Urban & 600 & 0.19 & 0.00 \\
\hline Dressler 1987 (65) & Rural & 147 & 0.82 & 0.72 \\
\hline Dressler 1996 (64) & Rural & 93 & 0.00 & 0.00 \\
\hline Dressler 1997 (62) & Urban & 205 & 0.51 & 0.26 \\
\hline Elder 1998 (66) & Migrants & 277 & 0.19 & 0.21 \\
\hline Elford 1990 (67) & Urban & 3,566 & 0.19 & 0.13 \\
\hline Espino 1990 (68) & Rural & 622 & 0.07 & NR \\
\hline Flemming-Morgan 1991 (69) & Urban and Rural & 158 & -0.44 & -0.37 \\
\hline Florey 1968 (70) & Urban and Rural & 733 & 0.28 & 0.44 \\
\hline Fulmer 1963 (71) & Urban and Rural & 4,208 & 1.06 & 0.91 \\
\hline Gampel 1962 (72) & Urban and Rural & 149 & -0.34 & -0.34 \\
\hline Garcia-Palmieri 1970 (73) & Urban and Rural & 8,785 & 0.37 & 0.39 \\
\hline Gilberts 1994 (74) & Rural & 620 & 0.25 & 0.25 \\
\hline Goldbourt 1991 (75) & Migrants & 530 & 0.16 & 0.63 \\
\hline
\end{tabular}


Acculturation and BP 39

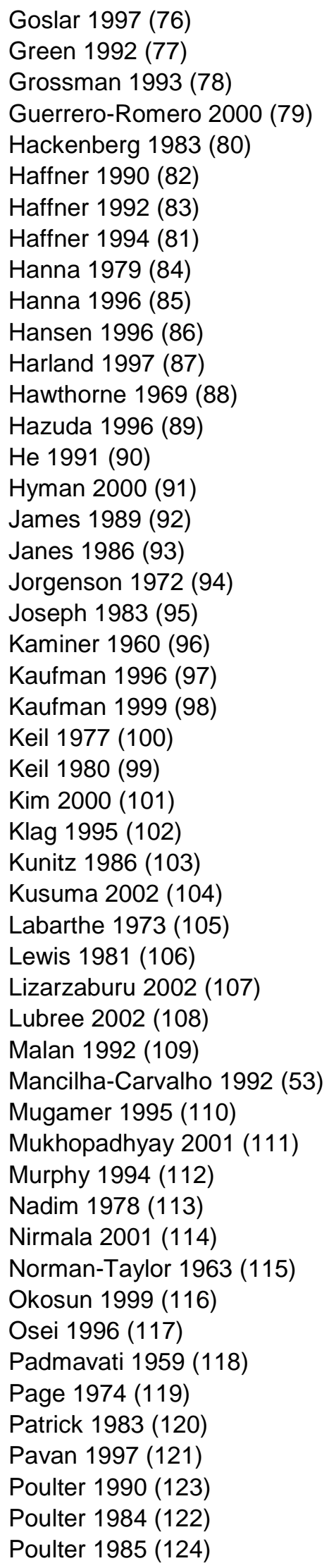

\begin{tabular}{|c|c|c|c|}
\hline Urban & 2,350 & -0.41 & -0.29 \\
\hline Urban & 5,147 & 0.40 & NR \\
\hline Migrants & 584 & 0.54 & 0.63 \\
\hline Urban and Rural & 1,790 & 0.97 & 0.22 \\
\hline Urban and Rural & 48,817 & 0.08 & 0.10 \\
\hline Urban and Rural & 5,170 & 0.05 & 0.06 \\
\hline Urban and Rural & 1,462 & 0.00 & NR \\
\hline Urban and Rural & 3,780 & 0.11 & 0.05 \\
\hline Migrants & 386 & -0.29 & -0.07 \\
\hline Urban and Rural & 187 & 0.17 & -0.07 \\
\hline Urban & 119 & -0.25 & NR \\
\hline Urban & 1,005 & -0.02 & -0.29 \\
\hline Urban and Rural & 461 & 0.07 & -0.41 \\
\hline Urban and Rural & 1,702 & 0.11 & 0.05 \\
\hline Urban and Rural & 10,513 & 0.36 & 0.47 \\
\hline Urban & 182 & 0.63 & 0.16 \\
\hline Urban and Rural & 123 & 0.24 & 0.65 \\
\hline Migrants & 2,353 & 0.68 & 0.76 \\
\hline Rural & 1,077 & 0.33 & 0.32 \\
\hline Migrants & 1,851 & 0.16 & 0.20 \\
\hline Rural & 63 & 1.29 & 0.69 \\
\hline Urban and Rural & 675 & 0.26 & 0.34 \\
\hline Migrants & 282 & 0.37 & NR \\
\hline Urban and Rural & 214 & -0.32 & 0.10 \\
\hline Urban and Rural & 417 & 0.89 & 0.29 \\
\hline Migrants & 1,528 & 0.19 & 0.72 \\
\hline Urban and Rural & 1,144 & 0.78 & 0.63 \\
\hline Rural & 1,483 & 0.22 & NR \\
\hline Urban and Rural & 450 & 0.50 & 0.12 \\
\hline Urban and Rural & 510 & 0.53 & 0.14 \\
\hline Urban and Rural & 314 & 0.18 & 0.10 \\
\hline Migrants & 258 & 0.33 & 0.37 \\
\hline Urban and Rural & 441 & 0.28 & 0.60 \\
\hline Urban and Rural & 30 & 1.35 & 1.35 \\
\hline Rural & 254 & 0.39 & 0.31 \\
\hline Urban and Rural & 322 & 0.18 & 0.00 \\
\hline Urban and Rural & 346 & 0.06 & 0.23 \\
\hline Urban and Rural & 142 & -0.75 & 0.00 \\
\hline Rural & 1,139 & 0.49 & 0.84 \\
\hline Urban and Rural & 1,184 & 0.54 & 0.64 \\
\hline Rural & 713 & 0.12 & -0.10 \\
\hline Urban and Rural & 8,982 & 0.05 & 0.28 \\
\hline Migrants & 58 & 0.37 & 0.79 \\
\hline Urban and Rural & 691 & 0.19 & 0.07 \\
\hline Rural & 1,235 & 0.42 & 0.23 \\
\hline Urban and Rural & 723 & -0.26 & -0.03 \\
\hline Urban and Rural & 740 & 0.70 & 0.98 \\
\hline Migrants & 637 & 0.78 & 0.87 \\
\hline Urban and Rural & 1,473 & 0.13 & 0.22 \\
\hline Urban and Rural & 1,181 & 0.46 & 0.6 \\
\hline
\end{tabular}


Acculturation and BP 40

Prior 1968 (125)

Proctor 1996 (126)

Reddy 1994 (127)

Reed 1970 (128)

Rosenthal 1990 (129)

Salmond 1985 (130)

Salmond 1989 (131)

Seedat 1982 (132)

Sever 1980 (133)

Sharper 1969 (134)

Sherman 1998 (135)

Silman 1987 (136)

Sobngwi 2002 (137)

Somova 1995 (138)

Taylor 1991 (140)

Taylor 1987 (139)

Taylor 1989 (141)

Taylor 1999 (142)

Timio 1997 (143)

Tomson 1994 (144)

Torun 2002 (145)

Tracy 1999 (146)

Tsugane 1989 (147)

Ulman 1975 (148)

Van den Hoogen 2000 (149)

Van Rooyen 2002 (150)

Van Rooyen 2000 (151)

Villela 2000 (152)

Walsh 1980 (154)

Walsh 1986 (153)

Ward 1980 (155)

Wilks 1996 (156)

Williams 1993 (157)

Zerba 1990 (158)

Zimmet 1980 (159)

Zimmet 1980 (160)
Urban and Rural

Children

Urban and Rural

Urban and Rural

Migrants

Migrants

Migrants

Urban and Rural

Urban and Rural

Military Group

Students

Migrants

Urban and Rural

Students

Migrants

Migrants

Urban and Rural

Urban and Rural

Urban and Rural

Migrants

Migrants

Urban

Migrants

Migrants

Urban

Urban and Rural

Migrants

Rural

Migrants

Urban

Migrants

Urban and Rural

Migrants

Rural

Urban and Rural

Urban and Rural
822

88

380

1,214

5,577

812

251

1,936

251

60

68

772

2,465

2,902

1,024

1,143

2,632

94

282

3,449

473

553

584

12,692

4,893

223

1,821

81

75

137

1,061

8,488

159

3,249

306

1,488
1.28

0.22

$-0.06$

0.04

0.68

0.02

1.83

0.17

0.39

1.08

0.85

0.22

0.17

0.14

$-0.08$

0.22

0.09

$-0.10$

0.44

0.42

0.00

0.54

0.30

0.16

0.35

0.64

0.14

$-0.19$

0.52

$-0.32$

0.20

0.11

0.00

0.23

0.17

0.53
1.06

0.26

0.24

0.07

0.70

0.11

1.53

NR

0.52

0.42

0.72

0.17

0.08

NR

0.17

0.22

0.17

0.12

0.44

0.35

0.04

0.54

0.24

0.15

0.39

1.07

0.22

$-0.02$

0.77

$-0.60$

0.18

0.19

0.00

$-0.02$

0.30

0.48

Note. $\mathrm{N}=$ number of participants. $\underline{\mathrm{d}}=$ standardized mean difference. SBP $=$ Systolic blood pressure. DBP $=$ Diastolic blood pressure. $\mathrm{NR}=$ Not reported . 
Acculturation and BP 41

Table 2

Random Effects Weighted Mean Effect Sizes (ㅁ) Across Levels of Several Moderator Variables in Studies Evaluating Blood Pressure in Association with Acculturation.

\begin{tabular}{|c|c|c|c|c|c|c|c|c|}
\hline \multirow[b]{2}{*}{ Variable } & \multicolumn{4}{|c|}{ Systolic Blood Pressure } & \multicolumn{4}{|c|}{ Diastolic Blood Pressure } \\
\hline & $\mathrm{Q}_{\mathrm{b}}$ & $\mathrm{p}$ & $\mathrm{k}$ & $\underline{\mathrm{d}}$ & $\mathrm{Q}_{\mathrm{b}}$ & $\mathrm{p}$ & $\mathrm{k}$ & $\underline{\mathrm{d}}$ \\
\hline Measurement of Blood Pressure & 4.9 & .03 & & & 4.7 & .03 & & \\
\hline Single Reading & & & 29 & .37 & & & 26 & .39 \\
\hline Multiple Readings (averaged) & & & 88 & .24 & & & 80 & .26 \\
\hline Type of Acculturation Evaluated & 11.2 & .003 & & & 11.4 & .003 & & \\
\hline Westernization/Industrialization & & & 69 & .22 & & & 60 & .26 \\
\hline Migration to a Western Society & & & 34 & .40 & & & 33 & .43 \\
\hline Adaptation to a Host Culture & & & 10 & .28 & & & 9 & .20 \\
\hline Rural/Urban Population Groups & 6.9 & .07 & & & 19.7 & .0002 & & \\
\hline Rural & & & 11 & .24 & & & 10 & .29 \\
\hline Urban & & & 14 & .15 & & & 12 & .02 \\
\hline Combined Rural/Urban & & & 54 & .26 & & & 50 & .27 \\
\hline Migrants from Rural to Urban & & & 27 & .37 & & & 27 & .44 \\
\hline Length of Acculturation & 23.9 & .0001 & & & 24.9 & .0001 & & \\
\hline 0-3 months & & & 6 & .66 & & & 6 & .65 \\
\hline 3 months to 3 years & & & 7 & .52 & & & 8 & .57 \\
\hline 3 years to 15 years & & & 15 & .38 & & & 14 & .33 \\
\hline More than 15 years & & & 31 & .23 & & & 27 & .22 \\
\hline Born in the host culture & & & 41 & .27 & & & 40 & .29 \\
\hline Region of Data Collection & 11.0 & .09 & & & 20.7 & .002 & & \\
\hline Africa & & & 21 & .32 & & & 18 & .36 \\
\hline Asia & & & 12 & .24 & & & 12 & .30 \\
\hline Central/South America & & & 14 & .33 & & & 14 & .27 \\
\hline Europe & & & 13 & .36 & & & 11 & .13 \\
\hline North America & & & 30 & .18 & & & 26 & .22 \\
\hline Middle-East & & & 10 & .48 & & & 10 & .65 \\
\hline Polynesia & & & 21 & .32 & & & 19 & .30 \\
\hline
\end{tabular}


Note. $Q_{b}=$ Q-value for variance between groups. This statistic is comparable to the F-value in ANOVAs. $k=$ number of studies. $\underline{d}=$ standardized mean difference, the effect size used in this meta-analysis to indicate the magnitude of differences in participants' blood pressure as a function of acculturation. 


\section{Magnitude of Effect Size (d) by Type of Acculturation Evaluated}

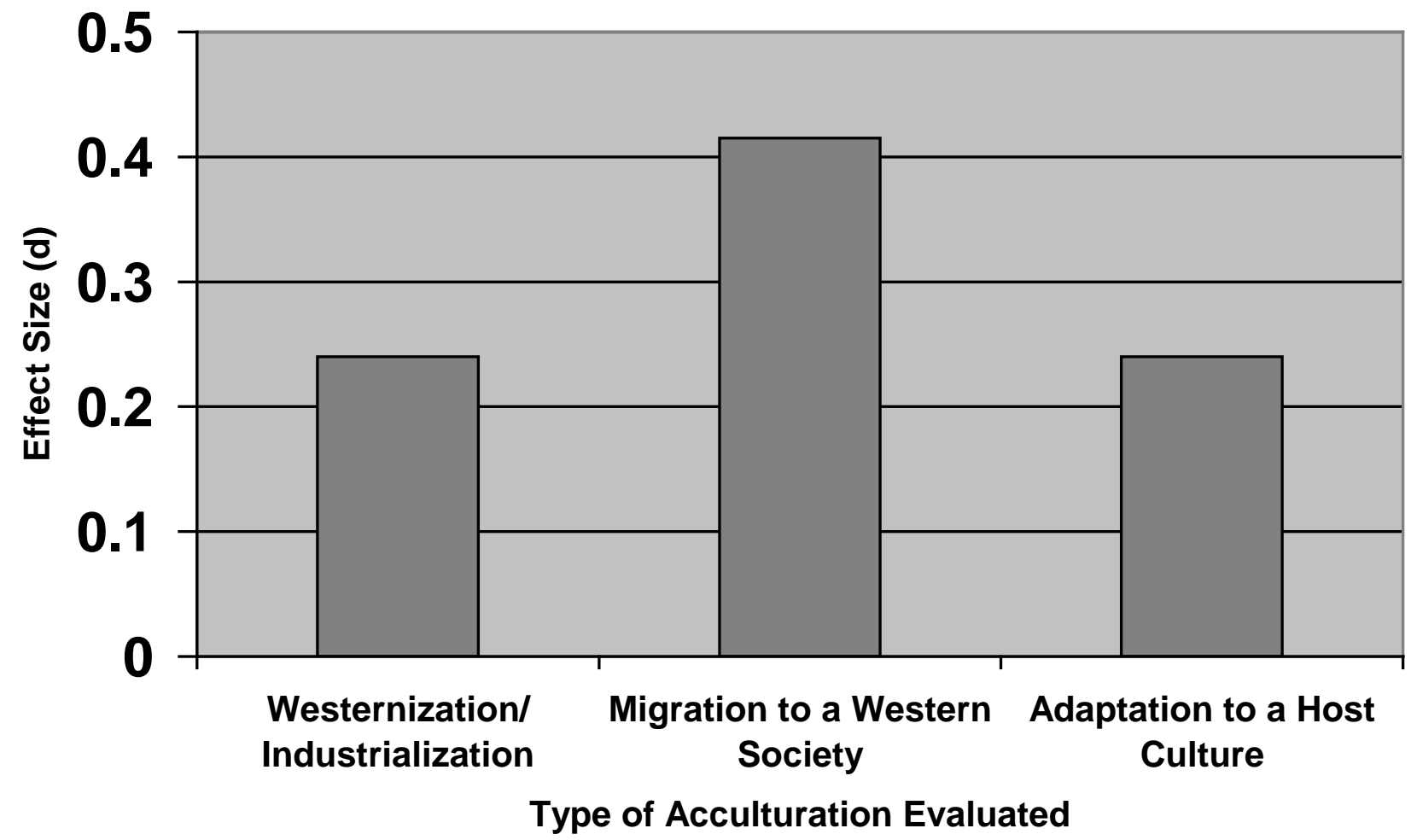

Figure 1. The largest effect sizes for acculturation on blood pressure were found among nonWesterners who migrated from their country of origin to a Western society, indicating that large cultural changes are strongly associated with increases in blood pressure. 


\section{Magnitude of Effect Size (d) by Length of Acculturation}

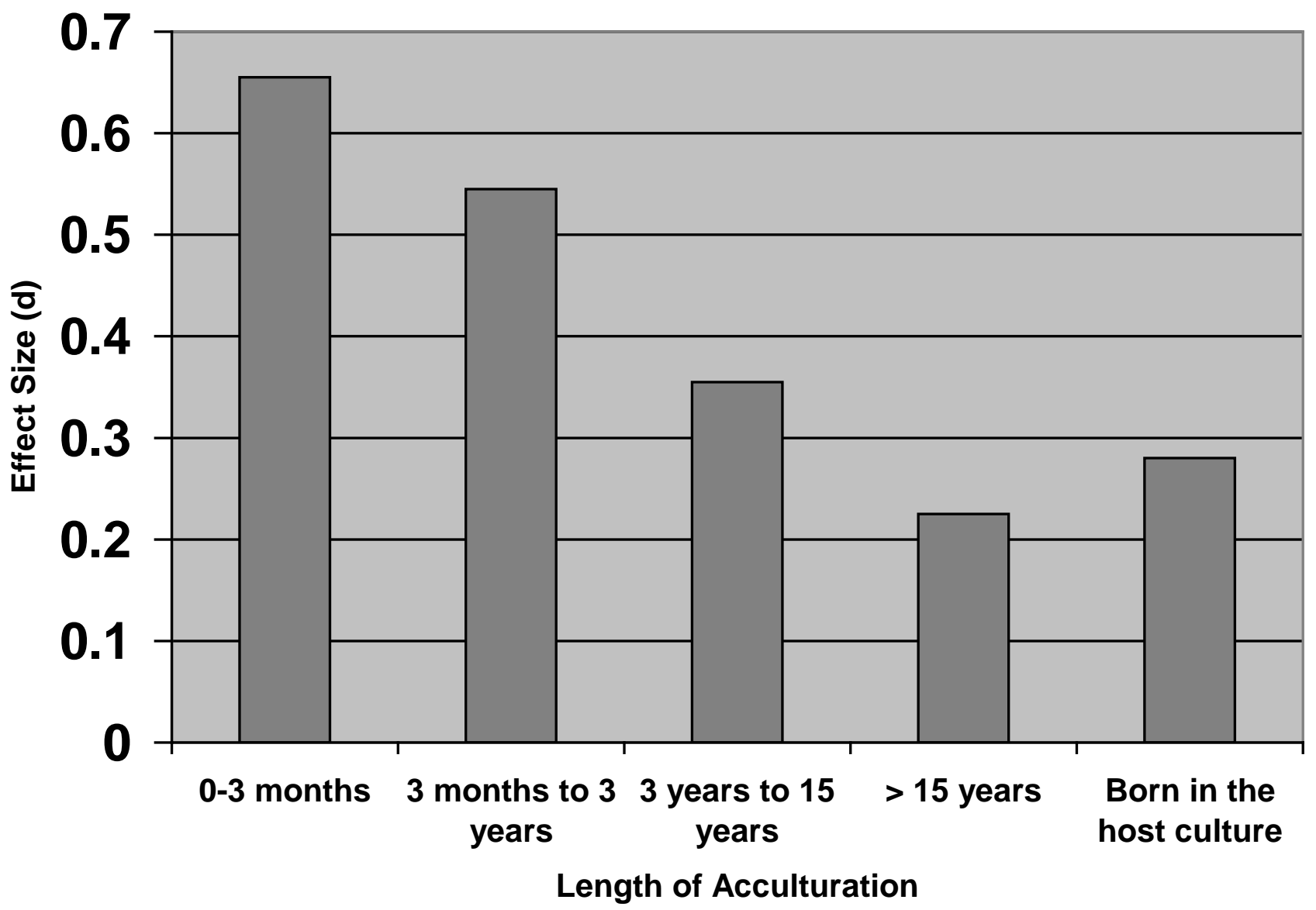

Figure 2. The largest effects sizes for acculturation on blood pressure were observed within 3 years of acculturating. This provides support to the hypothesis that the stress of cultural change plays a significant role in the acculturation process. 